\title{
General concept of wound healing, revisited
}

\author{
Theddeus O.H. Prasetyono \\ Division of Plastic Surgery, Department of Surgery, Faculty of Medicine University of Indonesia/ Cipto Mangunkusumo Hospital, \\ Jakarta, Indonesia
}

\begin{abstract}
Wound healing is a transition of processes which is also recognized as one of the most complex processes in human physiology. Complex series of reactions and interactions among cells and mediators take place in the healing process of wound involving cellular and molecular events. The inflammatory phase is naturally intended to remove devitalized tissue and prevent invasive infection. The proliferative phase is characterized by the formation of granulation tissue within the wound bed, composed of new capillary network, fibroblast, and macrophages in a loose arrangement of supporting structure. This second phase lasts from day 8 to 21 after the injury is also the phase for epithelialisation. The natural period of proliferative phase is a reflection for us in treating wound to reach the goal which ultimately defines as closed wound. The final maturation phase is also characterized by the balancing between deposition of collagen and its degradation. There are at least three prerequisites which are ideal local conditions for the nature of wound to go on a normal process of healing i.e. 1) all tissue involved in the wound and surrounding should be vital, 2) no foreign bodies in the wound, and 3) free from excessive contamination/infection. The author formulated a step ladder of thinking in regards of healing intentions covering all acute and chronic wounds. Regarding the "hierarchy", of healing intention, the first and ideal choice to heal wounds is by primary intention followed by tertiary intention and lastly the secondary intention. (Med J Indones 2009; 18: 208-16)
\end{abstract}

\begin{abstract}
Abstrak
Penyembuhan luka merupakan sebuah proses transisi yang merupakan salah satu proses paling kompleks dalam fisiologi manusia yang melibatkan serangkaian reaksi dan interaksi kompleks antara sel dan mediator. Fase peradangan bertujuan untuk membuang jaringan mati dan mencegah infeksi. Fase proliferasi bercirikan terbentuknya jaringan granulasi yang disertai kekayaan jaringan pembuluh darah baru, fibroblast, dan makrofag dalam jaringan penyangga yang longgar. Fase kedua yang berlangsung sejak hari ke- 8 hingga ke-21 pascaluka merupakan fase terjadinya epitelisasi dan sekaligus memberikan refleksi dalam perawatan luka untuk dapat mencapai kondisi luka yang telah tertutup dengan epitel. Fase terakhir adalah fase maturasi yang bercirikan keseimbangan antara proses pembentukan dan degradasi kolagen. Setidaknya terdapat 3 prasyarat kondisi lokal agar proses penyembuhan luka dapat berlangsung dengan normal, yaitu: 1) semua jaringan di area luka dan sekitarnya harus vital, 2) tidak terdapat benda asing, 3) tidak disertai kontaminasi eksesif atau infeksi. Penulis mengusulkan formulasi pola hirarkis dalam intensi penyembuhan luka yang mengikuti urutan intensi primer sebagai intensi ideal, diikuti intensi tersier, dan yang Vsekunder. (Med $\boldsymbol{J}$ Indones 2009; 18: 208-16)
\end{abstract}

Key words: inflammatory mediator, epithelialisation, growth factor, wound healing

A wound is generally recognized as a raw surface on the skin caused by various type of injury or disease. The most universal concept of wound is related to raw surface while we understand that not every wound has lost its surface epithelial coverage as we may see on skin e.g. with bruises due to direct injury. According to such a concept, once the epithelial coverage of skin is destroyed, then a wound is formed because of some area of skin losses its outer epithelial layers regardless the cause.

How long would be the best time to have wound epithelialised? The question can be transformed to a more universal and easier to understand: how long would you need if you have a laceration on your arm due to an accidently knife cutting? The answer may vary to such a given question when a group of layman people is being asked. They may give their opinion that they need from some minutes or hours to some days or weeks. The discussion will reveal a clarification that naturally human beings want their wounds to be healed as soon as possible; the sooner the better and the soonest the best. A new clean lacerated wound would be best treated with direct cleansing and suturing at the initial presentation. 
A subsequent question may arise: how long would be the best time to get a wound healed? A healed wound is actually in the end stage of healing. It is to be considered whenever we are treating any wound as plastic surgeon will always look in the future whenever they are managing defects. In other words, we need to foresee the future end result of the scar as a result of the current treatment we are giving. Anatomical location and region has a role in the length of healing time which naturally needs much longer than a raw surface needs (time) to get epithelial cover. This article will provide the reader with a practical overview of wound healing that spread from the initial injury to the end stage of scar.

\section{SKIN AND PHASES OF WOUND HEALING}

\section{Skin and the Role of Its Epithelial Cells}

As the widest organ of human body which has no least than 1-2 $\mathrm{m}^{2}$, skin in regards of cutaneous healing acts as a general representation of tissue healing because it is easily seen on its surface. Skin has multi functions besides its main function as general protector to cover the tissue structure and organ from any potential injury e.g. mechanically against pressure and friction, protector against chemical injury, thermally against heat, cold and radiation injury, and defensive structure against microbes, as well as to reduce water and heat loss. Beyond its function as protector, skin has unique function in terms of regulator of circulation and temperature and sensor for pressure, touch, pain, and temperature. Through its pores and extensive vascular plexuses, skin has a tremendous capacity in regulating the body temperature and circulation. In a low temperature, the pores shrink and vascular plexuses constrict to reduce the heat loss and keep the body in its optimum temperature. On the other hand when the body is in an environment with relatively high temperature, the pores open and the vessels dilate to keep the body from heat stroke. Another unique function that the skin bears is its use in sensing stimuli of pressure, touch, pain, and temperature which give comfort and advancement in many aspects of human being's life.

Histologically skin has two functional layers compring of the dermis and epidermis. The epidermal layer as the outermost layer is exactly the layer that we discussed in the above as the epithelial coverage. Whenever disruption of epidermal layers goes deeper than the keratin layer exposing the lucidum, granulosum, spinosum, and basal layers, it produces wound. This superficial wound heals fast involving their owned epithelial progenitor cells rich layers. The epithelial cells from those layers migrate and proliferate, healing the wound in 2-3 days, leaving relatively inconspicuous scar. The more superficial the disruption, the more perfect the scar resulted. Among those epidermal layers, the basal layer is the main healing source of epithelial cells especially in terms of cell replication. In clinical practice, this kind of superficial wound would heal secondarily without special treatment. The nature heals the wound nicely. Practitioner may apply vaseline or paraffin only if needed.

A disruption that goes deeper reaching the dermis will need more effort, energy, and longer time of healing. In this deeper healing, the basal layer still plays very important role because of its capacity to migrate covering the raw surface from periphery. If the wound is small, less than $1 \mathrm{~cm}$ in diameter, then the wound will be completely covered by epithelial layer in approximately a week to become a "closed" wound. In the case of much wider area of superficial wound involving superficial dermis, the wound may be covered by epithelial layer in the same time or a slightly longer. Anyhow, the process in terms of epithelial cells role is different. Cells from the deeper dermis play important role in the epithelialization. The sources of epithelial cells are the skin appendages i.e. hair follicles, sweat glands, and sebaceous glands. Furthermore, they take over the role of basal layer because the cells from this layer migrate slowly and shortly only.

\section{Phases of Wound Healing}

Understanding wound healing involves much more effort than simply stating there are three phases: inflammation, proliferation, and maturation. New mediators are discovered each year and our understanding of inflammatory mediators and cellular interactions grows. ${ }^{1}$ Inflammatory mediators involved in wound healing comprise 1) eicosanoids (prostaglandins, prostacyclins, thromboxanes, leukotriens, lipoxins), 2) cytokins (chemokines, lymphokines, monokines, interleukins, colony-stimulating factors, interferons, tumor necrosis factor), 3) nitric oxide, and 4) growth factors. ${ }^{2}$ Briefly, wound healing is a transition of processes which is also recognized as one of the most complex processes in human physiology. Complex series of reactions and interactions among cells and mediators take place in the healing process of wound, ${ }^{3,4}$ which needs more attention and studies to better heal the patient in the future. All the phases of healing involve cellular and molecular events. Whatsoever in clinical practice, the three phases of heal- 
ing which are distinct but overlapping is still important to understand and universally considered because it may provide us a guidance of physiology of wound healing and a frame of time to refer.

\section{Inflammation phase}

The first phase of wound healing starts from immediately upon injury and may last until four to six days. ${ }^{1}$ In other literature, the phases of healing are classified into four phases by differentiating the hemostasis as the first phase,${ }^{4}$ meanwhile generally it is known as part of the inflammatory phase. This initial phase is naturally intended to remove devitalized tissue and prevent invasive infection ${ }^{5}$ and characterized by an increase in vascular permeability by thrombin following hemostasis, secretion of chemotactic cytokines that facilitate the migration of cells. ${ }^{6}$ Wounding disrupt tissue vascular supply and the body initiates a cascade of events that allows itself to heal. ${ }^{6}$ Collagen exposed during wound formation activates the clotting cascade, both the intrinsic and extrinsic pathways, ${ }^{1}$ that culminates in the formation of a fibrin clot and hemostasis ${ }^{5}$ initiating the inflammatory phase. ${ }^{1,6}$ The fibrin clot serves as scaffolding for arriving cells, such as neutrophils, monocytes, fibroblasts, and endothelial cells. ${ }^{1}$ Polymorphonuclear leucocytes and macrophages are the dominant cell types during this initial stage. ${ }^{6}$ The fibrin clots/ provisional matrix also serves to concentrate the cytokines and growth factors ${ }^{1}$ that are released by platelet, thrombin, and fibronectin. Removal of provisional fibrin matrix will impair wound healing. ${ }^{5}$

Neutrophils are the first responders to the cellular distress signal and the chemotactic signal (by the cytokines) arriving into the fibrin clot. ${ }^{1}$ Furthermore the nearby blood vessels vasodilate and more neutrophils are drawn into the injured area by interleukin (IL)-1, tumor necrosis factor (TNF)- $\alpha$, platelet factor (PF)-4, transforming growth factor (TGF)- $\beta$, platelet derived growth factor (PDGF) 1,4 and "bacterial products." These PMN leucocytes begin clearing the invading bacteria and cellular debris. ${ }^{1}$ Monocytes will be attracted to the injured area and transform into macrophage in around 48 to $72-96$ hours after injury. ${ }^{1,5}$ Macrophages phagocytose debris and bacteria, but are critical for the orchestrated productions of growth factors necessary for production of the extracellular matrix by fibroblasts and the production of the new blood vessels. ${ }^{5}$ This is in accordance with un understanding that an activated macrophage is also important for the transition into the proliferative phase because it will mediate angio- genesis, fibroplasias, and synthesize nitric oxide. ${ }^{1}$ In summary, the healing process begins with hemostasis, platelet deposition, and interactions of soluble mediators and growth factors with the extracellular matrix. ${ }^{4}$

\section{Proliferation phase}

Proliverative phase is characterized by the formation of granulation tissue within the wound bed, composed of new capillary network, fibroblast, and macrophages in a loose arrangement of supporting structure. ${ }^{6}$ Besides formation of granulation tissue with its collagen and connective tissue proteins deposition and angiogenesis, epithelialization is also the principal step ${ }^{1,7}$ in this building part of wound healing. This second phase will start on day 45-7 concurrent with the waning of the inflammatory phase and go on until 146-215 days after the injury.

Angiogenesis is marked by endothelial cell migration and capillary formation. ${ }^{1}$ It is a natural response of healing to replace the injured microcirculation and involves the movement of endothelial cells in response to the three waves of growth factors i.e. PDGF, TGF- $\beta$, insulin-like growth factor during the inflammatory phase; fibroblast growth factor (FGF) released from normal binding sites on connective tissue molecules as the second wave; and vascular endothelial growth factor (VEGF) delivered by macrophages as the third and dominant wave. ${ }^{7}$ Angiogenesis progresses proportional to blood perfusion and arterial partial pressure of oxygen. ${ }^{7}$ New blood vessel grow into the collagen matrix formed by fibroblast.

PDGF and epidermal growth factor (EGF) which are derived from platelets and macrophages are the main signals to fibroblasts. ${ }^{1,5}$ Fibroblasts migrate into the wound site from the surrounding tissue, begin to synthesize collagen and proliferate. In response to PDGF, fibroblast synthesize provisional matrix composed of collagen type-III, glycosaminoglycans, and fibronectin1 that provides a platform for keratinocytes migration. ${ }^{5}$ Another type of fibroblasts is "wound fibroblasts" which already located in the wound site. This type of fibroblasts will transform into myofibroblasts which plays role for wound contraction. ${ }^{1}$ Myofibroblast is no other than fibroblast with intracellular actin microfilaments capable of force generation and matrix contraction. ${ }^{5}$ Myofibroblast contract the wound through specific integrin interactions with the collagen matrix. ${ }^{5} \mathrm{Clinically,}$ wound contraction is a natural response from the body to localize and make the area smaller protecting itself 
from all negative impacts of wounding. Wounds that heal by itself without special care show this powerful action of wound contraction.

Actually epithelialization start to occur immediately after wounding and stimulated by the inflammatory cytokins. 1 IL-1 and TGF- $\alpha$ upregulate keratinocyte growth factor (KGF) gene expression in fibroblast. Fibroblast will then synthesize and secrete KGF-1, KGF-2 (most important in human being), and IL-6 which stimulate neighboring keratinocytes to migrate in wound area, proliferate and differentiate in the epidermis. ${ }^{1}$ Lastly, epithelialization is characterized by replication and migration of epithelial cells across the skin edges.

\section{Maturation/ remodeling phase}

The final but longest phase of wound healing is the maturation process, which involves ongoing remodeling of granulation tissue beneath the newly formed epithelial layer and increasing wound tensile strength. ${ }^{7}$ This phase is recognized to start in overlapping with the proliferative phase from $8^{1}$ to $21^{5}$ days after the injury until one year afterwards. The main characteristics of this important phase is the deposition of collagen in a well-mannered nerwork ${ }^{1}$ which imply to collagen remodeling and scar contraction. ${ }^{5}$ The movement of fibroblasts pulls collagen fibers together, promoting contraction of the scar tissue. ${ }^{7}$

Type III collagen that is produced and deposited by fibroblast during the proliferative phase will be replaced by type I collagen over the next few months through a slow process of type III collagen degradation. ${ }^{5}$ The degradation is mediated through matrix metalloproteinases (MMP) secreted by macrophages, fibroblasts, and endothelial cells. ${ }^{5}$ The tensile strength (a strength to resist breaking) of a healing scar improves slowly, reflecting the turnover of the collagen subtypes and increase collagen crosslinking. At 3 weeks, the beginning of maturation phase, wounds only have approximately $20 \%{ }^{5}$ to $30 \%^{1}$ of the strength of normal skin, and will eventually only posses $70 \%{ }^{4}$ to $80 \%{ }^{1}$ of the normal strength at the end of the remodeling phase.

This final phase is also characterized by the balancing between deposition of collagen and its degradation. When collagen deposition or synthesis is impaired, then it will compromise the scar tissue tensile strength.
An atrophic scar might be the end result after the completion of the maturation phase. On the contrary, when the collagen degradation is impaired or its synthesis is excessive, the scar tissue may become hyperthrophic scar or even keloid. The ideal condition would be the balance between degradation and synthesis or deposition of collagen to produce a normal scar tissue.

\section{IDEAL CONDITIONS TO HEALING WOUND}

There are at least three pre-requisites which are ideal conditions for the nature of wound to go on a normal process of healing. Eventually these pre-requisites are not the only factors to allow wounds to heal normally as there are other factors that affect physiologic response and cellular function in the vulnerable healing wounds. Those pre-requisites are 1) all tissue involves in the wound and surrounding should be vital, 2) no foreign bodies in the wound, and 3 ) free from excessive contamination/ infection.

\section{All tissue involved is viable}

It is a general rule that necrotic tissue should be removed in order not to inhibit wound healing ${ }^{1,8}$ because the energy to heal the wound will be exhaustedly drifted into the effort of autolysis the necrotic tissue by the body itself. Consequently the wound will be more vulnerable to more interruption e.g. by infection, and local and systemic metabolic disorders. A clinical situation such as traumatic crush or degloving injury on lower extremity might be an example of discussing this first pre-requisite. (Figure 1) During a thorough debridement in the emergency setting, we may find difficulties in assessing the viability of all injured tissue. This might be easier if the team is capable to do extensive debridement under the principals of "no touch technique" like dealing with cancer surgery with a strong team of microsurgery where a huge defect can be closed easily with free flap transfer. ${ }^{9}$ Beyond that capability, many doctors are usually defensive from extensive debridement to avoid facing challenging wide raw surface which in turn needs big donor tissue to cover. But whatsoever, such a deed will only hide complex problems temporarily as consequences rather than effectively and efficiently treating the wound. 


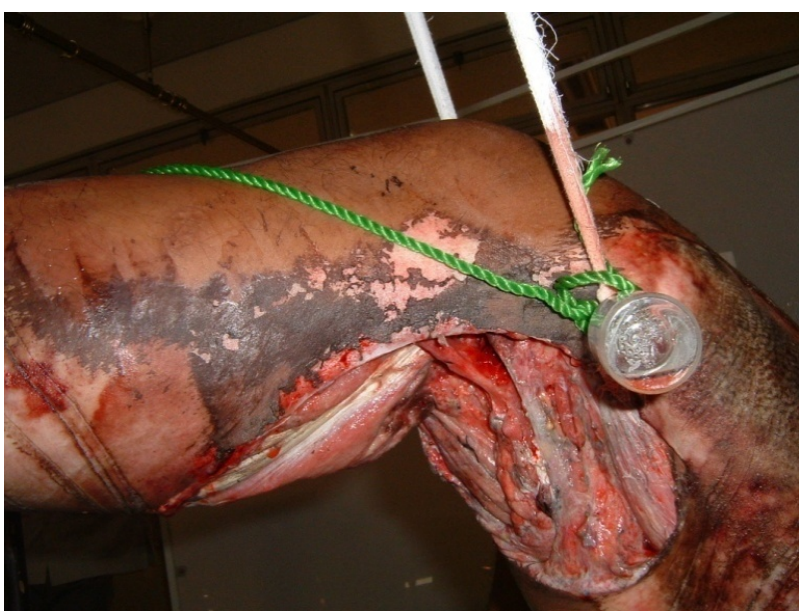

Figure. 1. A patient with history of crush injury has undergone initial debridement in the emergency setting. Some difficulties including the assessment on tissue viability were encountered by the medical team. On the next day after initial debridement, it revealed that more necrotic tissue appeared on the surrounding skin and underlying muscular tissue

Tissue ischemia is the main enemy we are facing in such a case which give complexity in assessing the viability of the tissue involved in the wound and its surrounding tissue. Physiologic response of the vascular endothelium to localized hypoxia or ischemia is to precipitate vasodilation, stimulate fibrin deposition, and increase proinflammatory activity, capillary leak, and neovascularisation. ${ }^{1}$ Vasodilation, capillary leak due to disturbance of its permeability, together with the activity of pro-inflammatory mediators causing edema. Edema and increased locally pressure associated with ischemic injured tissue will further compromise perfusion. ${ }^{1}$ Effective cell migration and molecular exchange will be disturbed.

The endothelial cell response to sustain hypoxia will result in endothelial cell apoptosis. ${ }^{1}$ It means that more microvasculatures will stop from their function supplying nutrients and oxygen. Unsustainable anaerobic condition will position the wound away from the ATP as the energy currency needed by energy-dependant healing. The condition will be even more deteriorated in the case of ischemia and necrosis.

Most of oxygen consumed in a wound is used for oxydant production (for bacterial killing), with a significant contribution as well for collagen synthesis, angiogenesis, and epithelialization. ${ }^{7}$ Nutrients and oxygen supplied by the capillaries are essential in the formation of granulation tissue, ${ }^{1}$ leading to the need to ensure the adequate oxygen delivery to the wound..$^{10}$ Not only nutri- ents and oxygen, but the migration of cells and enzymes are also lacking in the wound. Failure of such supply to occur will result in chronically unhealed wound. Besides growth factors, lactate and hypoxia induce collagen mRNA synthesis and procollagen production. Hydroxylases is required to allow collagen peptides to aggregate into triple helical structure because collagen can only be exported from the cells in this structure. ${ }^{7}$ The activity of hydroxilases is critically dependent on vitamin $\mathrm{C}$ and tissue oxygen tension. Wound strength, which results from collagen deposition, is, therefore, highly vulnerable to wound hypoxia.7 One other thing to be considered is that epithelialization depends on local oxygen in vivo. ${ }^{7}$

\section{No foreign bodies}

Wound with foreign bodies cannot contract, repopulate the area with capillaries, or completely epithelialize (depending on the size and location of the foreign bodies). ${ }^{1}$ The author has an experience on a 12 year-old female patient who came with small ulcer just next the left commissural. (Figure 2) She had been suffering from that recalcitrant granuloma for a year and been shopping for doctors and clinics but never healed. Exudation and pustulation had been waving on the presentation of the chronic granulating tissue that never healed. Simple excision of the ulcer revealed two pieces of bamboo in the chronic wound, and simple suturing healed the wound uneventfully. Other example that quite common encountered by plastic surgeons is the infected implant in situ. The only treatment that is effective to heal the wound is to remove the implant with subsequent repair of the resulting defect.

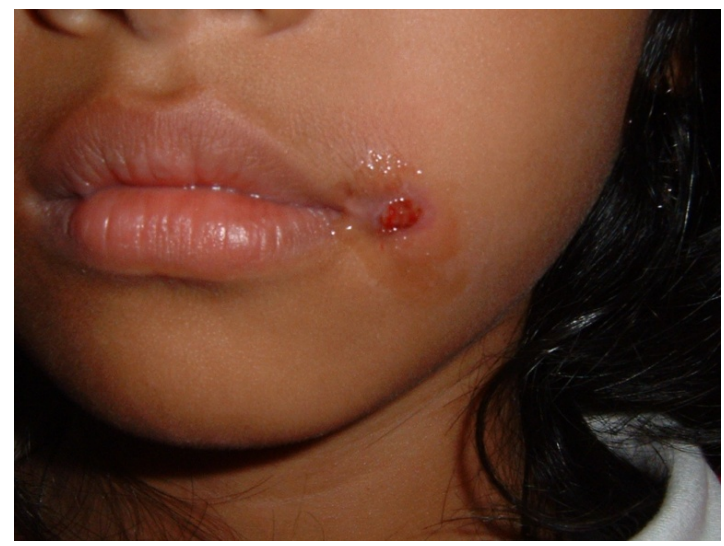

Fig. 2. A 12 year-old girl has had a small granulating wound since a year before presentation. Surgical removal of the wound revealed also 2 pieces of bamboo inside the chronic wound 


\section{Free from excessive contamination/ infection}

Although bacterial colonization can be found in any wounds, especially chronic wounds, usually normal healing can occur. An infected wound has different history; it does not progress through the stages of wound healing ${ }^{6}$ because the energy to heal the wound is exhaustedly used to fight bacterial burden. Wound will suffer from metabolic load imposed by bacteria (bacterial bioburden). It remains in the inflammatory phase $\mathrm{e}^{1,6}$ and interfere with the epithelialization, contraction, and collagen deposition. ${ }^{1}$ The endotoxins that are released when the bacteria is killed, will stimulate phagocytosis and the release of collagenase, which contribute to collagen degradation and destruction of surrounding, previously normal tissue. ${ }^{1}$

In a more clinical comprehensive wound management factors that should be considered are the systemic factors, not only those three pre-requisites which refer mostly the local factors. Local factors may include also radiation and neoplasm, while systemic factors that are also detrimental to wound healing are diabetes, hypothyroidism, smoking, nutrition, aging, medications (chemotherapy), exogenous steroid administration, ${ }^{1,6}$ major trauma, sepsis, specific organ failure, and radiation. ${ }^{1}$

\section{ACUTE AND CHRONIC WOUND}

An acute wound is simply recognized as a wound that has occurred within the past 3 weeks or in some literature it may be to 4 weeks. ${ }^{5}$ Wounds that persist until more than 3 to 4 weeks are considered as chronic wounds. The same term is used for any wounds that last longer, months to years, as it happens on diabetic foot ulcers and gangrene, pressure sores, ulcers due to chronic vein insufficiency or occlusive arterial diseases, radiation injury. Non healing wounds and delayed healing wounds are the terms interchangeably used to describe no other than chronic wounds. ${ }^{5}$ Inadequately healing wound seems to refer to supposedly normal healing wound but external and technical factors negatively impact the process as we can see on wound dehiscence. Use of the term difficult to treat wounds ${ }^{11}$ may comprise both the acute and chronic wounds. The last mentioned here is not referring the period of time that has elapsed for wound to heal, rather the future and natures of wounds that potentially need sophisticated surgical technique to cover the wound, acute wounds accompanied with non supportive local and systemic factors to heal, or chronic wounds that has been proven to be difficult to treat.

In the old paradigm of understanding wound healing, an acute wound is seen easily to heal which is right, but looking at the many factors involved in the healing then we consider an acute wound should be treated intensively as chronic wounds from the onset, if systemic and local factors are expected to impact the healing. ${ }^{10}$ Chronic wounds are often referred to as a "granulating" pointing to the appearance in the wound cavity or surface of granulation tissue which appear to be red and fragile (easily to bleed). ${ }^{5}$ Such an appearance of granulation tissue is a sign that suggest that the wound is progressing, albeit slowly. ${ }^{5}$

\section{CHARATERISTIC OF CHRONIC WOUNDS}

Pathological response to injury will end up with chronic wounds where the normal healing process is disrupted. Independent assessment on every wound may reveal the factors, systemically and locally, for which they play role in disturbing the healing process. Of those factors, wound infection is implicated most commonly as a cause for poor wound healing ${ }^{12}$ and may complicate the inheritance of wound which has already had predisposing factors to develop chronic wound such as in diabetic foot, pressure sore, venous and arterial ulcers.

Eventually, once a wound is created there is a $100 \%$ probability of it being contaminated ${ }^{13}$ within 48 hours. ${ }^{14}$ Based on bacterial presence, wound can be classified into four levels i.e. 1) contaminated wounds which have non-proliferating bacteria, 2) colonized wounds within which proliferating bacteria present, 3) critically colonized wounds where the proliferating bacteria have reached a level that interferes with healing, but without classic signs of infection, 4) infected wounds which have multiplying bacteria in the presence of host reaction. ${ }^{14}$ Chronic wounds is always contaminated and even inherit bacterial colonization which may become infection on a later stage if not well managed.

Most patients with normal immune systems can heal wounds contaminated with up to $10^{5}$ organisms per gram of tissue ${ }^{1,12}$ Other literature showed the amount of bacteria to cause infection is greater than $10^{4}$ per gram of tissue ${ }^{13}$ or with a density of more than $10^{5}$ colonyforming bacterial units per cubic millimeter of tissue. ${ }^{14}$ Wounds will not heal by any means, including primary suture, skin graft placement, or flap closure, if bacterial count exceeds the above mentioned critical amount or if any $\beta$-hemolytic Streptococcus is present. ${ }^{1}$ The healing in decubitus ulcers is inhibited if the bacterial load is greater than $10^{6} \mathrm{CFU}$ (colony forming units)/ $\mathrm{ml}$ of wound fluid. ${ }^{13}$ Characteristics of infected wounds would include but not limited to the existence of change 
of exudate both in terms of quantity and quality. The amount of exudate may be greater when previously colonization becomes infection. Excessive amount of exudate will be more prominent as a sign of infection as well as its quality which is previously serous, that change into e.g. pustulation or serohemorhagic fluid. Other signs of local inflammation will accordingly be the signs of infection.

Repeated injury and ischemia due to any insults including infection will stimulate pro-inflammatory cytokins to inhibit the wound healing. ${ }^{13}$ TNF- $\alpha$ and IL-1 will increase their activity causing subsequent increasing level of proteases including MMPs (matrix metalloproteninases) and elastase and decreasing level of TIMPs (tissue inhibitor of matrix metalloproteinases).${ }^{13}$ Chronic wounds have a cycle of cellular activity that does not support healing, proteolytic activity can be inappropriate, levels of MMPs and serine proteases increase while TIMP decrease, lactate level falls down, albumin, total proteins and glucose levels in the wound rise. All those conditions will result in the decrease level and activities of growth factors/ receptors, connective tissue deposition, cell migration, and ECM (extracellular matrix) degradation. ${ }^{13}$ Of those deterioration can be reflected in the study of chronic wound exudate. Thus, exudate which is a "healing balsam" in the acute wounds, is not a healing agent in terms of chronic wounds. Exudate in the chronic wounds should be well treated in order not to further stop the wound from healing.

\section{THE STEP LADDER OF THINKING FOR WOUND CLOSURE}

The goal of wound management should be a closed healing wound with functional and aesthetically satisfactory scar. The achievement can be elaborated to become good or excellent scar when we deal with acute wound in normal healing. The nomenclature of both scientific and clinical wound healing research is imprecise and confusing. ${ }^{5}$ To reduce the complexity of different various terms in wound healing, the author will provide a simple discussion on this matter.

As mentioned above, a new laceration will be best treated by cleansing and suturing it which also means to end up as a "closed" wound. Wound closure at the initial presentation is classified as healing by primary intention as it is usually elaborated by surgeon dealing with incisional wounds. ${ }^{5}$ Primary healing without complications would be always the main healing intention for every wound made purposively. A big wound resulting from tumor removal that cannot be closed by primary suturing will need skin graft or flap to close it. The first intention of this type of wound closure follow the same principal as the healing by primary intention as long as it will end up without complications. Generally such wounds do not require special wound care after the success of skin graft or flap.

The above mentioned primary healing is in contrast to wounds that are not reapproximated for any reason and the subsequent defect is "filled in" with granulation tissue and then reepithelialised. ${ }^{5}$ The history of the healing mode of such wounds without surgical intervention follows the secondary intention which usually results in a delay of "closed" wound. The timing for the healing by secondary intention is apparently limited to 3 weeks in a normal healing process regarding the proliferation phase which is included with epithelialization. Often these wounds would not heal by themselves fulfilling the process in 3 weeks to become "closed" wounds without dressings and treatments. Special care to unique wounds would be needed unless they will easily become chronic.

Where would be the place for wound to heal by tertiary intention? Surgeons frequently deal with wounds needed treatment under this mode of tertiary healing. For example a shearing force injury producing big non non-viable avulsion flap on the cruris would need excision. For some reasons not all the wound area can be closed primarily in the emergency setting. After several days of conservative management through wound bed preparation, then further surgery would be needed to close the wound by any means in the armamentarium of plastic reconstructive surgery, including bioengineered skin product. Wounds that undergo some period of secondary healing or becoming chronic wounds before surgical intervention to produce "close" wounds are healed by tertiary intention.

Regarding the "hierarchy" of healing intention, the first and ideal choice to heal wounds is by primary intention. Of course there is a place to let acute wounds to heal by secondary intention, for example we deal with excoriations, donor area of split thickness skin graft, etc. The next choice to heal wounds would be by tertiary intention especially when we deal with chronic wounds; not by secondary intention. This concept follows idea explored from the layman people discussed in the introduction section of this review as representations of our patients that they would vote for the idea of healing as soon as it can be. Chronic wounds may 
needs weeks, months, or even years to become "close" wounds under the intention to heal them secondarily. No one would prefer to take this possibility which elaborates only conservative wound management involving either "old fashion" or advance interactive dressings. Dressing and all wound bed preparation are the technique to guide and facilitate wounds, especially chronic wounds, to be ready for tertiary intention healing. Secondary intention of healing is in the lowest step ladder of wound management. But eventually, not every chronic wound is suitable to be treated by surgical interventions by any reasons; in this case, we would prefer to heal them by secondary intention.

\section{UNIVERSAL CONCEPT OF MOIST WOUND HEALING}

In the old paradigm of wound management, wounds were traditionally managed by the concept of wet to dry dressings which has changed in turn into wet to moist dressing. With the advanced progress of technology, the old paradigm has shifted to become a new one elaborating the moist wound healing alleviating the need to be wet at the beginning. Gauze as the previously universal surgical dressing has been changed into advance wound dressings tailored to wounds to suit the dynamic process of healing, especially in regards of various levels of exudate and colonization-infection.

Moist dressing has been an advance elaboration of the traditional concept to prevent wounds from bacterial invasion, further mechanical-thermal-chemical trauma, and heat and water loss, while keeping its semipermeability. It protects the wounds from dehydration and further desiccation. A "film of moisture," instead of scab formation, produced by a moist dressing facilitates epithelialization to take place and keeps the vascular plexuses where they have started since the beginning of wound creation. On the contrary where the wound situation is without moisture and scab develops from desiccation, the vascular plexuses in the dermis will be eroded and lost. Further advantage of ideal moist dressing is its ability to keep the amount of exudate normal, where water soluble substances such as amino acids, sugar, and electrolytes, are available for new cells formation. The transport of mediators will also run normally, and it can provide ideal condition for immune defense response.

The concept of moist wound healing has facilitated chronic wound management, and led to numerous dressing materials to control surface moisture. ${ }^{15}$ This moisture concept has been elaborated in the principals of managing wound to prepare its bed; it is called as TIME which refer to $\mathrm{T}$ for the removal of unhealthy and non-viable tissue, I for the control of infection and reduction of bacterial load, $M$ for the maintenance of moisture balance, and $\mathrm{E}$ for advancing the wound edge. ${ }^{15}$ In terms of moisture balance, the wound should be kept moist but not overly exudative. Furthermore, moist wound healing should be in accordance with the concept of exudate removal in the management of chronic wounds.

\section{REFERENCES}

1. Broughton II G, Janis JE, Attinger CE. Wound healing: an overview. Plast Reconstr Surg. 2006; 117 (Suppl): 1eS-32eS.

2. Leahy PJ, Lawrence T. biologic enhancement of wound healing. Clin Plast Surg. 2007; 34(4): 659-71.

3. Rumalla VK, Borah GL. Cytokines, growth factors, and plastic surgery. Plast Reconstr Surg. 2001; 108(3): 719-33.

4. Chin GA, Diegelmann RF, Schultz GS. Cellular and molecular regulation of wound healing. In: Falabella AF, Kirsner RS, editors. Wound healing. Boca Raton: Taylor \& Francis Group; 2005.p. 17-38.

5. Gurtner GC. Wound healing: normal and abnormal. In: Thorne CH, Beasley RW, Aston SJ, Barlett SP, Gurtner GC, Spear SL, editors. Grabb and Smith's plastic surgery. 6th ed. Philadelphia: Lippincott Williams \& Wilkins; 2007.p. 15-22.

6. Myers WT, Leong M, Phillips LG. Optimizing the patient for surgical treatment of the wound. Clin Plast Surg.2007; 34(4): 607-20.

7. Ueno C, Hunt TK, Hopf HW. Using physiology to improve surgical wound outcomes. Plast Reconstr Surg. 2006; 117 (Suppl): 59S-71S.

8. Steed DL. Debridement. Am J Surg. 2004; 187(5): S71-4.

9. Prasetyono TOH, Aniko G. Severe soft tissue damage accompanying open fracture of the lower extremity: plastic surgery point of view. Indones J Plast Surg 2003; 2(2): 66-72.

10. Galiano RD, Mustoe T. Wound care. In: Thorne CH, Beasley RW, Aston SJ, Barlett SP, Gurtner GC, Spear SL, editors. Grabb and Smith's plastic surgery. 6th ed. Philadelphia: Lippincott Williams \& Wilkins; 2007.p. 23-32.

11. Prasetyono TOH. Negative-pressure wound therapy for difficult to treat wounds. J I Bedah Indones (Indones J Surg). 2005; 33(2): 55-61.

12. Knox KR, Datiashvilli RO, Granick MS. Surgical wound bed preparation of chronic and acute wounds. Clin Plast Surg.2007; 34(4): 633-41.

13. Schultz GS. The physiology of wound bed preparation. In: Granick MS, Gamelli RL. Surgical wound healing and management. New York: Informa Health Care; 2007.p. 1-16

14. Morin RJ, Tomaselli NL. Interactive dressings and topical agents. Clin Plast Surg.2007; 34(4): 643-58.

15. Granick MS, Chehade M. the evolution of surgical manage- 
ment: toward a common language. In: Granick MS, Gamelli RL. Surgical wound healing and management. New York: Informa Health Care; 2007.p. 17-27. 